\title{
May You Live In Interesting Times
}

\section{WhAT NOW, BEPS?}

The ambitious and comprehensive Action Plan on Base Erosion and Profit Shifting (BEPS) endorsed by the G20 to the OECD in 2013, has reached an important turning point. As planned, thirteen reports were delivered after two years of mandate. They aim at reducing losses of revenue arising from a variety of interrelated causes, namely the interaction of domestic tax rules, the interaction of tax treaties, lack of transparency and coordination between tax administrations. ${ }^{1}$

The fight against aggressive tax planning by multinationals is a key element of the BEPS initiative, and social responsibility in the tax realm is being discussed in parliamentary hearings and in the media. ${ }^{2}$ Facing BEPS seriously involves the recognition that aggressive tax planning and the afore-mentioned causes are indicative of the inadequacy of the international tax system.

Both the monumental work carried out by the OECD and the deliverables for the Actions deserve to be celebrated. The time has now come to assess whether these reports are capable of achieving the main purposes of the BEPS initiative.

\section{A holistic ApProach to aggressive tax PLANNING}

The delivered BEPS package was supposed to address aggressive tax planning in a holistic manner. This concept is used in the BEPS Action Plan under Actions 1 and 5,3 but it underlies the overall spirit of the BEPS initiative. Indeed, expectations were high. ${ }^{4}$ This holistic approach can be interpreted in different ways.

Under a minor holistic approach, there is an objective to reform the international tax system, so that disparities (unintended gaps) are eliminated. A minor holistic approach may be carried out by progressively reforming the most problematic regimes that have led to aggressive tax planning. The objectives put forward by the G20 would simply imply working in the direction that was already being pursued by the OECD, but now at a much faster pace.

In turn, a moderate bolistic approach would imply reforming the most problematic regimes and aim at enforcing the single taxation principle by eliminating both unintended and intended gaps, without changing the core of the current system. At its core are the transfer pricing rules and the arm's length principle, and both would need to be improved.

Finally, a major bolistic approach would imply a replacement of the current international tax system by replacing the transfer pricing rules and arm's length method (by an indirect method), or even the corporate income tax itself.

The reports which were delivered by the OECD as part of the BEPS initiative and which are to be implemented in the coming years, reflect a mix of minor and moderate holistic approaches. The OECD recognizes that the BEPS initiative introduces a moderate reform of the international tax system:

[t]his package of 13 reports, delivered just 2 years later, includes new or reinforced international standards as well as concrete measures to help countries tackle BEPS. It represents the result of a major and unparalleled effort by OECD and G20 working together on an equal footing with the participation of an increasing number of developing countries. ${ }^{5}$

Regardless of how one interprets the meaning of 'holistic approach', it always requires coordination among

\section{Notes}

OECD, Explanatory Statement: 2015 Deliverables, OECD/G20 Base Erosion and Profit Shifting Project (OECD 2015), p. 4.

See Christiana Panayi, Is Aggressive Tax Planning Socially Irresponsible?, 43 Intertax 10, 544 (2015).

OECD, Action Plan on Base Erosion and Profit Shifting (OECD 2013), e.g., pp. 14, 18, 21.

See e.g., Yariv Brauner, Transfer Pricing in BEPS: First Round - Business Interests Win (But, Not in Knock-Out), 43 Intertax 1, 72 (2015).

OECD, supra n. 1. 
actions and coordination among countries. Realistically, however, both are difficult - if not impossible - to achieve.

\section{UNILATERALISM: COORDINATED OR UNCOORDINATED?}

The fact that several jurisdictions introduced unilateral measures before the final reports and BEPS package were delivered, illustrates that the stated aim of a holistic and coordinated approach is not being taken seriously. For example the United Kingdom (UK) introduced the socalled diverted profits tax, in force from 1 April 2015, anticipating any OECD amendments to the concept of permanent establishment under Action 7.6 The diverted profits tax is applied to non-resident UK companies carrying out activities in the UK in connection with supplies of goods or services to UK customers, where the activity is designed to ensure that the foreign company does not have a UK permanent establishment (PE) (the 'avoided PE'). The tax is also applied in situations where there is a UK company or a UK PE and the arrangements 'lack economic substance'.?

It remains to be seen whether either the recommendations under Action 7 ('Preventing the Artificial Avoidance of PE Status') or the UK regime (or both) will be followed as standards by other jurisdictions. They can be complementary, but the UK diverted profits tax is a measure outside the BEPS package that could lead to similar unilateral reactions - and therefore an uncoordinated allocation of taxing rights.

In 2014, France introduced anti-hybrid measures (primary response) as recommended by Action 2 (discussion draft). Article 212 of the French Tax Code, introduced after the Budget Law for 2014, aims at preventing so-called double-dip structures where interest is deductible in France without being taxed in the recipient's jurisdiction, mainly because of different characterizations of that interest. However, whereas under Action 2, the recommended primary rule is 'that countries deny the taxpayer's deduction for a payment to the extent that it is not included in the taxable income of the recipient in the counterpart jurisdiction', ${ }^{8}$ under the French rule, interest paid to a related entity is deductible to the extent that is subject to 'sufficient taxation' at the level of the recipient. 'Sufficient taxation' means 25\% of the French corporate income tax that would have been paid under ordinary French rules $(25 \%$ x $331 / 3 \%=8.33 \%) .{ }^{9}$ The French rule makes reference to neither the tax base (taxable income), nor to beneficial ownership. The question is whether the French rule complies with the primary rule in Action 2. It can also be asked whether the French rule is compatible with the amendment to the Parent-Subsidiary Directive, specifically Article 4(1)(a), under which the parent company of an European Union (EU) Member State must 'refrain from taxing such profits to the extent that such profits are not deductible by the subsidiary, and tax such profits to the extent that such profits are deductible by the subsidiary'. ${ }^{10}$

The 'primary response' has also been implemented in Austria, where the interpretation of Action 2 has been different than that in France. Under 'Article 12(1), no. 10 of the Austrian Corporate Income Tax Act (CITA), interest payments are not deductible at the level of the payor if the payments are made to a foreign corporation, the paying and the receiving company belong to the same group and the payment is not taxed at the level of the receiving company due to an exemption'. ${ }^{11}$

It can be argued that different interpretations of the BEPS recommendations are valid (and valuable), but it can also be asked whether it is legitimate for a country to neutralize insufficient taxation at the level of the recipient, and whether exemption corresponds to 'non-inclusion in [...] taxable income'.

Another example of implementation of BEPS recommendations, before the approval of the final package, are the Brazilian mandatory disclosure rules which were enacted by a Temporary Measure (Medida Provisória 685) on 21 July 2015. The Measure, which has not yet been approved by the Congress, is inspired by Action 12. It foresees that notice must be given to the tax authorities if transactions leading to the elimination, reduction or postponement of taxes if, among other things, they do not correspond to the contracts that are typically concluded (Article $7(2)$ ) or if there are no relevant reasons other than fiscal ones (Article 7(1)).

\section{Notes}

\footnotetext{
Heather Self, The UK's New Diverted Profits Tax: Compliance with EU Law', 43 Intertax 4, 333 (2015).

See Self, supra n. 3, p. 333.

Emphasis added.

See François Rontani \& Daniel Gutmann, 'Mauvaise année pour les instruments hybrides', Entreprise et Expertise fiscal, Option Finance 1252 (13 Jan. 2014$), 20-21$.

10 On the compatibility of the responses recommended by Action 2 and the EU fundamental freedoms, see Alexander Rust, BEPS Action 2:2014 Deliverable - Neutralising the Effects of Hybrid Mismatch Arrangements and Its Compatibility with the Non-Discrimination Provisions in Tax Treaties and the Treaty on the Functioning of the European Union, 3 British Tax Rev. 3, 308, 319-321 (2015). For a thorough discussion of Action 2, see also Reinout de Boer \& Otto Marres, BEPS Action 2: Neutralizing the Effects on Hybrid Mismatch Arrangements, 43 Intertax 1, 14 (2015).

11 Rust., supra n. 7, p. 311.
} 
Whereas Action 12 admits that disclosure may lead to (i) a tax reaction similar to that resulting from a general anti-avoidance rule (GAAR), and also (ii) legislative amendments in the case of legal gaps, the concepts adopted in Article 7(1) and (2) of the mandatory disclosure rules are so far unknown in the Brazilian tax legal system, and there is no GAAR under Brazilian law to combat tax abuse. It is at least debated whether implementation of approved mandatory disclosure rules would imply a disguised introduction of a GAAR. ${ }^{12}$

Beyond specific unilateral legal reactions, there is another angle of the BEPS impact, specifically judicial reactions to the BEPS initiative and output. The Spanish Supreme Court judgments of 9 February 2015 (188/2014 and 3971/2013) are illustrative of the influence of BEPS as a tool of soft law. In these two cases, the Spanish tax administration applied the Spanish GAAR to deny deduction of interest paid to a non-resident associated company. However, instead of interpreting the Spanish GAAR and its elements ('artificiality'), the Supreme Court stated that there was 'no economic reason behind the transaction'. Moreover, according to the Court, as the interest was not taxed in the hands of the group company that received the interest, there was illegal tax avoidance. The Supreme Court expressly referred to the factual situation as one that is being attacked in the context of the BEPS plan and the Commission's Communication on aggressive tax planning. ${ }^{13}$ Both the BEPS plan and the Commission Communication were used as legal arguments to interpret the Spanish GAAR.

If national Courts incorporate the BEPS principles in their legal reasoning, as legal arguments, multilateral coordination is hardly achievable. Similarly to the unilateral legal reactions, case law will lead to unilateral interpretations of vague principles and concepts.

The above examples of unilateral legal measures and case law demonstrate that countries are still pursuing national goals and national justice. ${ }^{14}$ These examples also demonstrate that multilateral coordination, as if there were an international tax system valid as an international standard of interest to each and every jurisdiction, is a myth. ${ }^{15}$ An international standard is not the right answer to the problems affecting the current international tax system.

Coordinated different standards, adopted by a number of jurisdictions with similar economic interests, would be more effective. Unilateral measures, such as those that are being adopted, may lead to increasing aggressive tax planning and exit if not all countries engage in similar measures or in the measures proposed by the OECD.

\section{CoORdinAtion AND COMPLEXITY}

A more serious problem arising from the BEPS project concerns the lack of consensus among jurisdictions, even in respect of minimum standards. This means that some measures will not be adopted; disparities (unintended gaps) will continue to exist; and uncertainty and complexity will increase.

On the contrary, even if all measures were adopted, it is not clear how they are to be interpreted or how they interact. Transfer pricing rules, such as rules regarding the allocation of taxing rights, are at the core of the BEPS Actions and work on three key areas: transactions involving intangibles; contractual allocation of risks; and other high-risk areas (Actions 8 through 10). They aim at allocating taxing rights according to the value created in the different jurisdictions. ${ }^{16}$ But if they fail, CFC rules can come into play and will reallocate taxing rights, even if this reallocation is not part of the G20 mandate to the OECD. ${ }^{17}$

In the final package, there is a clear effort to clarify the interaction and hierarchy among the proposed measures, for example, between Action 2 (Neutralising the Effects of Hybrid Mismatch Arrangements) and Actions 3, 4 and 5.18

Action 2 also attempts to distinguish between intended and unintended gaps as a condition for countries to adopt either the primary or the secondary answers, and even if it seems to suggest the implementation of a single tax principle' in the international tax system:

the fact that the mismatch can also be attributed to other facts (such as the fact that the payee is exempt)

\section{Notes}

12 Luis Eduardo Schoueri \& Ricardo André Galendi Júnior, Transparência Fiscal e Reciprocidade nas Perspetivas Interna e Internacional, Grandes Questões Atuais do Direito Tributário, 252-254 (2015).

EC Recommendation C-(2012)8806, 6 Dec. 2012

4 Tsilly Dagan, Tax Sovereignty in an Era of Tax Multilateralism, in EU BEPS: Fiscal Transparency, Protection of Taxpayers Rights and State Aid (Dennis Weber, ed., IBFD, forthcoming 2016).

15 For the validity of international standards, see Ana Paula Dourado, Exchange of Information and Validity of Global Standards in Tax Law: Abstractionism and Expressionism or Where the Truth Lies, EUI Working Paper, RSCAS 2013/11, available at http://cadmus.eui.eu/bitstream/handle/1814/26059/RSCAS_2013_11.pdf?sequence=1; Ana Paula Dourado, Is This a Pipe? Validity of a Tax Reform for a Developing Country, in Tax, Law and Development (Yariv Brauner \& Miranda Stewart eds, Elgar 2013 ), 127.

Critically, Brauner, supra n. 4

17 Ana Paula Dourado, The Role of CFC Rules in the BEPS Initiative and in the EU, 3 British Tax Rev., 349 (2015).

18 OECD, Neutralising the Effects of Hybrid Mismatch Arrangements - Action 2: 2015 Final Report, OECD/G20 Base Erosion and Profit Shifting Project (OECD 2014), pp. 97-98. 
will not prevent the rule from applying provided the mismatch would have arisen even in respect of the same payment between taxpayers of ordinary status. ${ }^{19}$

Even with the OECD guidance, coordination among rules will be complex; burdensome to taxpayers and the tax administrations; and ultimately impossible to administer. This will require a massive amount of information on the involved tax regimes: For example the application of both the primary and secondary responses under Action 2 involves information on the countries involved and possibly on beneficial ownership. In turn, Action 5 (Counter Harmful Tax Practices More Effectively, Taking into Account Transparency and Substance) aims to assess whether there is substantial activity in a country with a preferential regime. In the context of IP regimes, the 'nexus' approach was adopted.

However, given the results under Action 3, it seems that a CFC rule can be applied by jurisdiction $A$, even if the nexus approach is applied in jurisdiction $B$. Moreover, it seems that a CFC rule can still be applied as a backstop to Action 2.20

By playing the role of backstop measures, CFC rules, if widely adopted and strengthened, may contribute to reduce or neutralize tax competition among jurisdictions.

It can be rightly argued that it is not certain that CFC rules or strengthened $\mathrm{CFC}$ rules will be adopted in many jurisdictions, as tax competition is still a significant value to take into account.

\section{Conclusion}

In the current global tax good governance context, exchange of information is one condition for the BEPS initiative to be successful. Action 5 (Counter Harmful Tax Practices More Effectively, Taking into Account Transparency and Substance) foresees mandatory spontaneous exchange of information on rulings that could give rise to BEPS concerns. Actions 12 (Requiring Taxpayers to Disclose their Aggressive Tax Planning Arrangements) and 13 (Re-examining Transfer Pricing Documentation) are instruments to improved reactions by the tax administrations.

The issue is whether, ultimately, it would not have been preferable to continue working on increased international transparency and allow each jurisdiction or group of associated jurisdictions to find the adequate national tax policy for each national concept of tax justice. ${ }^{21}$

These are interesting times, times of disorder and trouble. The BEPS initiative, together with the international standards on fiscal transparency, have opened too many doors at once. It will take time to reach a new equilibrium.

Ana Paula Dourado Professor of the University of Lisbon

\section{Notes}

19 OECD, Neutralising the Effects of Hybrid Mismatch Arrangements, supra n. 18, p. 97.

20 Dourado, The Role of CFC Rules in the BEPS Initiative and in the EU, supra n. 17

21 See Dagan, supra n. 14. 